See discussions, stats, and author profiles for this publication at: https://www.researchgate.net/publication/326177248

\title{
Are Traditional NPD processes relevant to IoT product and service development activities; a critical examination
}

Conference Paper · June 2018

DOI: $10.21606 / d m a .2018 .244$

\section{CITATIONS}

0

3 authors:

๑

Boyeun Lee

Lancaster University

2 PUBLICATIONS 0 CITATIONS

SEE PROFILE

David Hands

Lancaster University

60 PUBLICATIONS 939 CITATIONS

SEE PROFILE

Some of the authors of this publication are also working on these related projects:

Project Liveable Cities project View project

Project PETRAS: Cybersecurity for the Internet of Things View project
157

A. Rachel F. D. Cooper

Lancaster University

187 PUBLICATIONS 2,914 CITATIONS

SEE PROFILE 


\title{
Are Traditional NPD Processes Relevant to loT Product and Service Development Activities? A Critical Examination
}

\author{
LEE Boyeun*; COOPER Rachel and HANDS David \\ Lancaster University \\ * Corresponding author email: b.lee12@lancaster.ac.uk \\ doi: 10.21606/dma.2018.244
}

\begin{abstract}
Increasingly physical products are being equipped with sensors, which connect them to the Internet; the network of these 'smart products' are acknowledged as the Internet of Things. These digitalized artefacts have a wide variety of material properties that could include a range of outcomes, such as new products, platforms, services, and other value pathways that differentiate them from their non-digital counterparts. Practitioners and researchers acknowledge that these differences influence tremendously on loT product and service development processes. These are significant for loT firms that occupy the market, due to a paucity of established literature on this theme; it is difficult to find studies on NPD processes, which reflects this digitization. This is an exploratory paper. That explores current literature prior to further empirical data collection. Through a critical examination of literature, this paper examines how smart product development processes are different from traditional product development processes. Thus, this paper offers critical insights and observations to enable both practitioners and academics to ascertain a detailed understanding of diverse approaches to NPD process activities for the loT.
\end{abstract}

new product development process; internet of things; digital innovation; big data

\section{Introduction}

By 2020, it is estimated that 50 billion devices around the world will be connected to the Internet (Cisco, 2011). This seemingly recent trend has been decades in the making, but is at a critical tipping point now (Burkitt, 2014). The loT era represents a transformative shift for the economy in which other major technology industry trends (e.g., cloud computing, data analytics, and mobile communications) can be incorporated (ibid, 2014). At present, the Internet of Things remains a fertile field for enterprises and so that in every six businesses is planning to roll out an loT-based product (ibid, 2014). It is anticipated that the amount of loT products will soon overtake the number 
of connected individuals: Gartner (2014) forecasts that the loT will reach 26 billion units by 2020, up from 0.9 billion in 2009, and will affect how organisations develop new products and services.

Consequently, the 'Internet of Things' (IOT) is becoming a popular theme of exploration amongst academics and industry practitioners, i.e. a new technological orientated paradigm regarded as a vision of connectivity, for anything, at anytime and anywhere, with an impact on everyday life more dramatic than the Internet had in the past twenty years (ITU 2005). IOT is also defined as "Interconnected objects having an active role in what might be called the Future Internet" (European Commissions Information Society, 2008). Such interconnected objects, so called 'smart products', have the capability to retrieve, store and share massive amounts of data which is also transforming business (Pisano, Pironti, \& Rieple, 2015) and NPD processes (Johnson, Friend \& Lee, 2017). Moreover, these pervasive adoptions of and innovations with digital technologies is radically changing the nature of products and services (Yoo, Boland, Lyytinen \& Majchzak, 2012) and therefore influencing NPD processes on smart products and services.

\subsection{Study Rationale}

With the emergence of loT as a new source of huge data, businesses face new opportunities as well as new challenges (Porter \& Heppelmann, 2014). Not only manufacturers but also the many various service industries are in the process of adoption of the loT to increase revenue through enhanced services and to lead the market (Lee \& Lee, 2015). The adoption of this technology is rapidly gaining momentum since technological, societal, and competitive pressures push companies to innovate and transform themselves (ibid, 2015). Although researchers and practitioners often critically debate the opportunities and challenges to the adoption of loT, not much attention has been focused on the New Product Development process of IoT; arguably one of the most critical marketing planning and implementation process activities. It is difficult to identify a generic NPD process, which reflects the rapidly growing digitization, as such, there is a paucity of studies on the differences between traditional NPD models and emergent approaches towards loT product and service development models.

\subsection{Research Goal, Questions and Methods}

This paper forms part of a summary of loT products development practices, and is focused on a critical examination of established NPD and NSD processes that are related to the development of loT products and services.

Its primary aim is to contribute to a deeper understanding of the loT product and service development processes. The paper provides insights with regard to establishing new approaches to the loT product development process, which could then enable academics and industry practitioners to better understand the process of developing loT products and services. The following research questions will be both offered and critically debated:

- What are the characteristics of existing NPD and NSD processes and their relevance to loT product and service development activities?

- What are the key factors affecting the development of loT NPD processes, and how do they differentiate them from their non-digital counterparts?

- What are the new attributes required by loT product and service development activities?

In order to answer these primary questions, this paper presents a common understanding of established NPD and NSD processes; then it offers a summary of relevant trends of loT, and closing with implications for emergent approaches towards the loT. The first stage focused on issues surrounding traditional NPD (Cooper, 1990; Booz, Allen \& Hamilton, 1982; Trott, 2012; Takeuchi \& Nonaka, 1986; Pennell, Winner, Bertrand, \& Slusarczuk, 1989; Crawford, 1997; Baker \& Hart, 1999; Cooper, 1994; Smith, 2007), NSD process (Johnson, Menor, Chase, \& Roth, 2000) and innovation process (Chesbrough, 2004) identify the common characteristics of existing development processes for products and services. Secondly, it examines the key factors in digital innovation which affect 
approaches towards the development of hybrid products and services, including six dimensions of digital innovation (Yoo, Lyytinen, Boland \& Berente, 2010); three dimensions of big data (McAfee \& Brynjolfsson, 2012; Meta Group, 2001); new opportunities in digital age (Henfridsson, Mathiassen \& Svahn, 2014) and three traits of innovations (Yoo et al, 2012). Finally, based on the study of NPD for IOT products and services, guidelines for developing smart products and services are then offered.

The research has involved an extensive examination of current literature surrounding these topics; articles and texts, which were broadly selected through searches of electronic databases such as Wiley Online Library Journals, Business Source Complete, ProQuest Business Premium Collection, Springer Journals Archive and Google Scholar. Search terms used, included 1) "NPD (New Product Development)", "NSD (New Service Development)", "design process", "Agile software development", "Innovation process", "Digital innovation process", Digital innovation management", 2) "IoT (Internet of Things)", "Smart product", "Hybrid product and service", and "Digital artefact". These were then supplemented by manual searches of abstracts of articles published in Journal of Product Innovation Management, Journal of Information Technology, Research Technology Management, Information Systems Research, Organisation Science, International Marketing Review, Journal of Marketing, and European Journal of Innovation Management. Each text was critically examined for their relevance to the central three themes or questions of study.

\section{The Internet of Things (IoT)}

The 'Internet of Things' is the combination of physical components (hardware), smart components (sensors, software and data analytics) and connectivity (wired or wireless connection) which empowers to improve value creation. The smart components elevate the capabilities of the physical product, whilst the connectivity components enhance the capability of the smart components. Connectivity allows loT products both the capability to exchange information between the product and its environment, whether that its user, the manufacturer or other smart products, and the capability to offer functions that exist outside the physical device (Porter \& Heppelmann, 2014).

IoT products provide geometrically expanding opportunities for new functionality, greater reliability, higher product utilization, and capabilities that cut across and exceed traditional product boundaries (Porter \& Heppelmann, 2014). loT is penetrating a wide range of industries including retailing, manufacturing, healthcare, insurance, home appliances, heavy equipment, airlines and logistics (Lee \& Lee 2015). These new types of products externally alter industry structures and boundaries but also internally re-shape the value chain by changing product design, marketing and manufacturing, and by demanding the need for product data analytics (Porter \& Hepelmann, 2014). Giudice (2015) argues that the loT utility is even reshaping innovation processes connected to products and services as well as interpreting the business process management in many sectors.

Whether companies are going to take either get-ahead strategy or catch-up strategy (Firms implementing get-ahead strategy, use innovation reputation to differentiate from their competitors, in contrast, implementing catch-up strategy, companies are able to remain efficient in order to survive, grow, and even overtake the leader's position), all companies often expect to have appropriate NPD processes to develop their own loT products or services in order to take advantage of loT innovations in the future. A new product development process for loT is therefore emerging where products consisting of electrical and mechanical parts become intelligent systems that combine hardware, software, control sensors, data storage and connectivity in infinite ways. With so much potential value in the investment of loT technology, organisations need to have an appropriate and efficient NPD process to minimize the risk of failure. As such, this paper will now review how traditional NPD and NSD have evolved and their characteristics before exploring their relevance to IoT and, new approaches toward loT product and service development(s). 


\section{New Product Development and New Service Development}

As contemporary competitive pressure and pace of technological change increases, corporations face the challenges of increasing efficiency, creating breakthroughs, and pre-empting competitors (Meyer \& Utterback, 1995; Kessler \& Bierly, 2002). In this context, the continual development of new products are generally admitted as a requirement for companies' growth and long-term prosperity. Consequently, the subject of New Product Development (NPD) has gained a considerable amount of attention from product development professionals and researchers over the decade (Durisin, Calahretta, \& Parmeggiani, 2010; Machado, 2013). A large number of academics has defined new product development, such as the transformation of a market opportunity and a set of assumptions about product technology into a product available for sale (Krishnan \& Ulrich, 2001). Bruce and Cooper (2000) argue it is a term used to capture a range of different types of innovative activities leading to the production of a new service or product from radical innovations to simple modification and adaptations to existing products.

Awwad and Akroush (2016) identify NPD efficiency as the most significant element to determine a company's competitiveness and survival, because it distinctively affects firm's financial performance. Thus, NPD is a fundamental business activity and as such "the development of new and improved products for the survival and prosperity of modern corporations" (Cooper, 2005). However, managing new product development is a challenging, complex and risky process (Bruce \& Cooper, 2000; Goffin \& Koners, 2011), as the failure rates of NPD are estimated about $40 \%$ of new products at launch, and further only $13 \%$ of companies report that their total efforts to NPD hit their annual profit objectives (Cooper, 2017). Hauser and Dahan (2007) argue that having a good NPD process is critical in terms of firms can efficiently managing the inherent risk of new product development.

Numerous NPD process models are characterized as step-wise approaches such as stage-gate system (Cooper, 1990) or The Booz, Allen and Hamilton model (Booz, Allen \& Hamilton, 1982) that managers are recommended to use (Harmancioglu, McNally, Calantone, \& Curmusoglu, 2007), which are clear and useful in terms of management (Eveleens, 2010), but also effectively acting as a blueprint for organizations to follow and adapt as required (Oorschot, Sengupta, Akkermans, \& van Wassenhove, 2010). However, these sequential models are regarded as relatively simple standard processes for NPD (Tidd \& Bessant, 2005; Bruce \& Cooper, p.11, 2000) and too prescriptive and mechanistic, therefore, fail to take into account overlaps of activities that will occur naturally in the workplace (Bruce \& Cooper, p.11, 2000). Moreover, these models can increase cycle time (Schilling \& Hill, 1998) so that besides the strength of the models, the weaknesses apparent in the sequential models led to the development of more complex models.

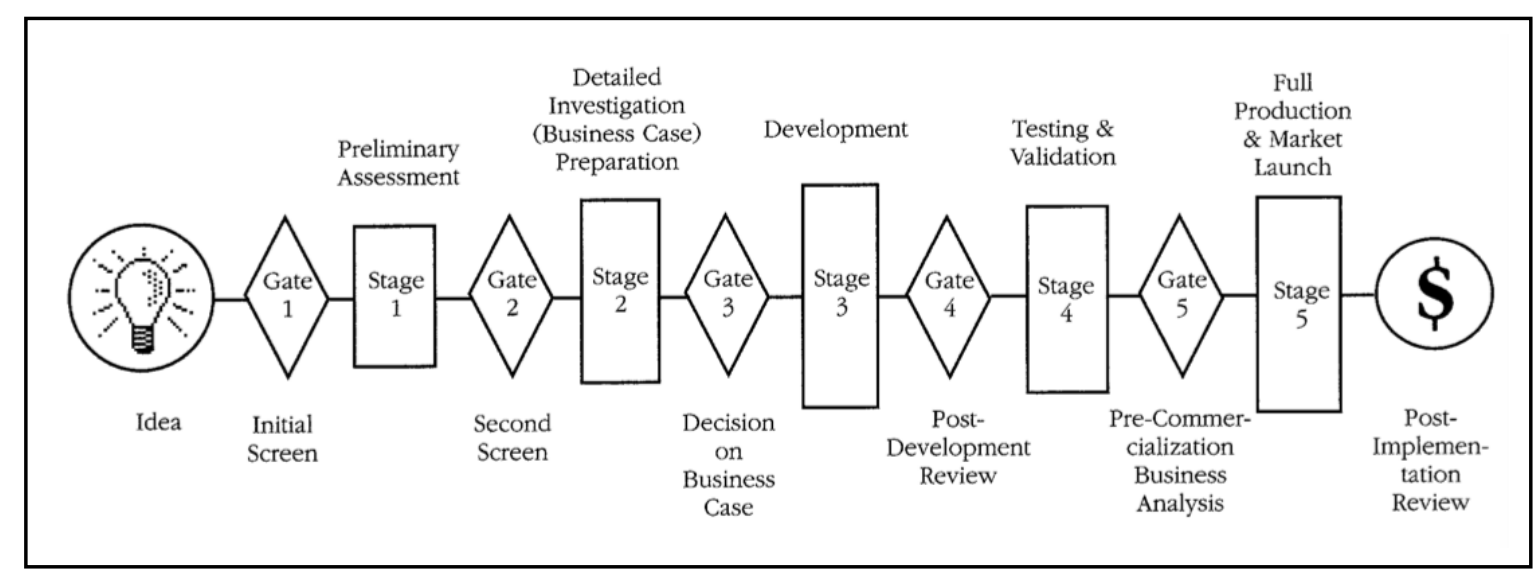

Figure 1 A Stage-Gate System. source: Cooper, R. G, 1990

Several researchers applied sequential models to the service development activity (Stevens \& Dimitriadis, 2005). Johnson, Menor, Chase, and Roth (2000) developed a model describing the NSD sequence which identifies 4 broad stages and 13 tasks that must be conducted to launch a new 
service, and the components of the organisation that are involved within the process. Although sequential NSD models provide a descriptive view of ongoing processes, they suffer from three major weaknesses as linear NPD models do: 1) time-consuming and overly bureaucratic processes slow projects down (Cooper, 1994); 2) each stage does not describe the way of integration that firms organise development teams (Stevens \& Dimitriadis, 2005); 3) linear models do not help to define what must be produced during each stage (ibid, 2005).

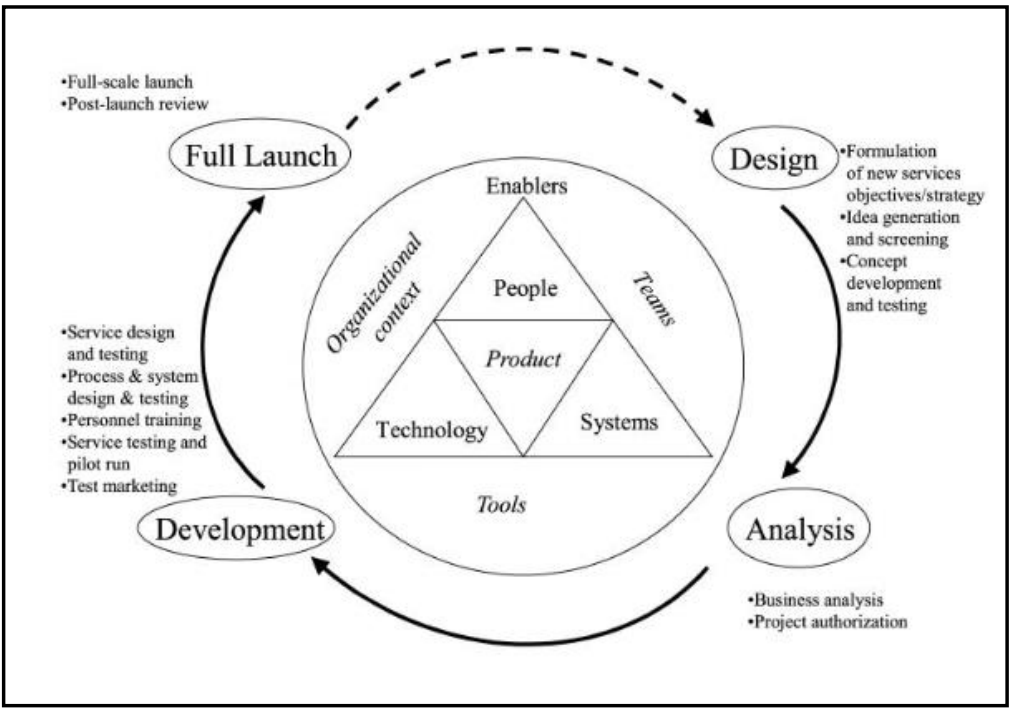

Figure 2 New Service Development Process. source: Johnson et al, 2000

From the idea to focus attention on the project as a whole rather than the individual stages (Trott, 2012), radically different approaches have emerged which are simultaneous approach such as parallel processing models (Takeuchi \& Nonaka, 1986), Concurrent Engineering (Pennell, Winner, Bertrand, \& Slusarczuk, 1989), Activity-stage models (Crawford, 1997), multiple convergent model (Baker \& Hart, 1999) and Third-generation model (Cooper, 1994). The key benefit of parallel processing NPD models is that they decrease time to market by reducing the cycle time (Anderson, 1993) and emphasises the need for a cross-functional approach (Trott, 2012). However, adopting parallel processing requires more effort from all departmental functions, more effective management, and large-scale organisational changes in routine (Bruce \& Cooper, 2000) so that most organisations are not willing to deal with the changes, altering the traditional method of NPD (Anderson, 1993).

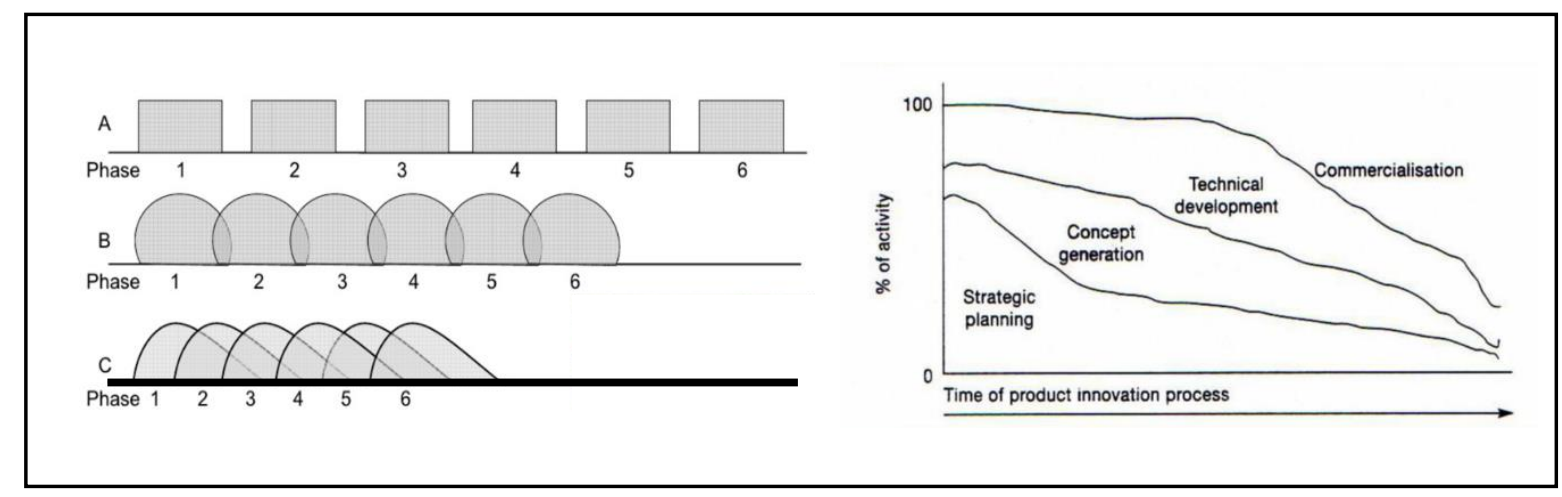

Figure 3 Left: Sequential (A) vs. Overlapping (B \& C) Phases of development. source: Takeuchi \& Nonaka, 1986; Right: Activity-Stage Model. Source: Crawford, 1997

Chesbrough's (2004) open innovation concept is not presented as a model of NPD as such; however, it has been highly influential in the areas of R\&D management, innovation, and NPD. It emphasises the significance of external network interactions in relation to NPD activities and this phenomenon 
has grown due to a number of factors such as the reduction of the product life cycle, the aggregation of global competition and the rising costs of research and development (Caputo, Lamberti,

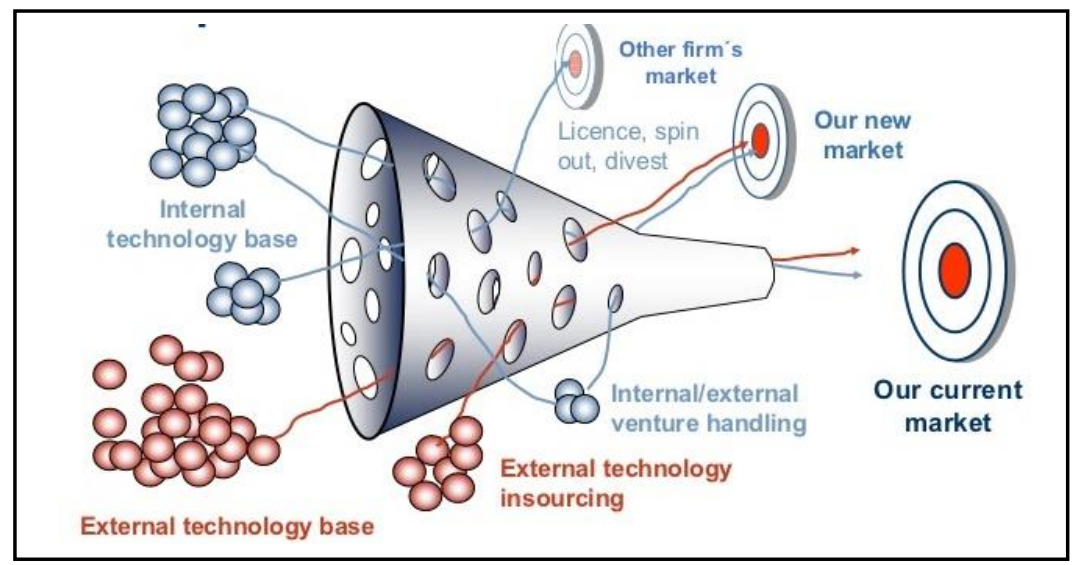

Cammarano, \& Michelino, 2016).

Figure 4 Open Innovation Model. source: Chesbrough, 2004, Presentation at $10^{\text {th }}$ Annual Innovation Convergence

Recently, flexible product development is the ability to make changes to the product being developed or in how it is developed (Smith, 2007) so that agile methodologies begins to attract interest from developers of physical products (Cooper, 2014; Ovesen \& Sommer 2012) who experienced the limitations and challenges of traditional waterfall product development approaches. Agile development method is for software development based on iterative and incremental process consists of a number of short development cycles, known as sprints (Beck, Beedle, van Bennekum, Cockburn, Cunningham, \& Flowler, 2001). It is argued that these 'sprints' improve communication and coordination activities, speed to market and faster responses to changed customer requirements or technical challenges (Begel \& Nagappan, 2007). However, since agile methodology is for software development, some challenges for manufacturers adopting agile practices have been identified, i.e. a lack of scalability, a proliferation of meetings, and a lack of effective management (Cooper, 2017).

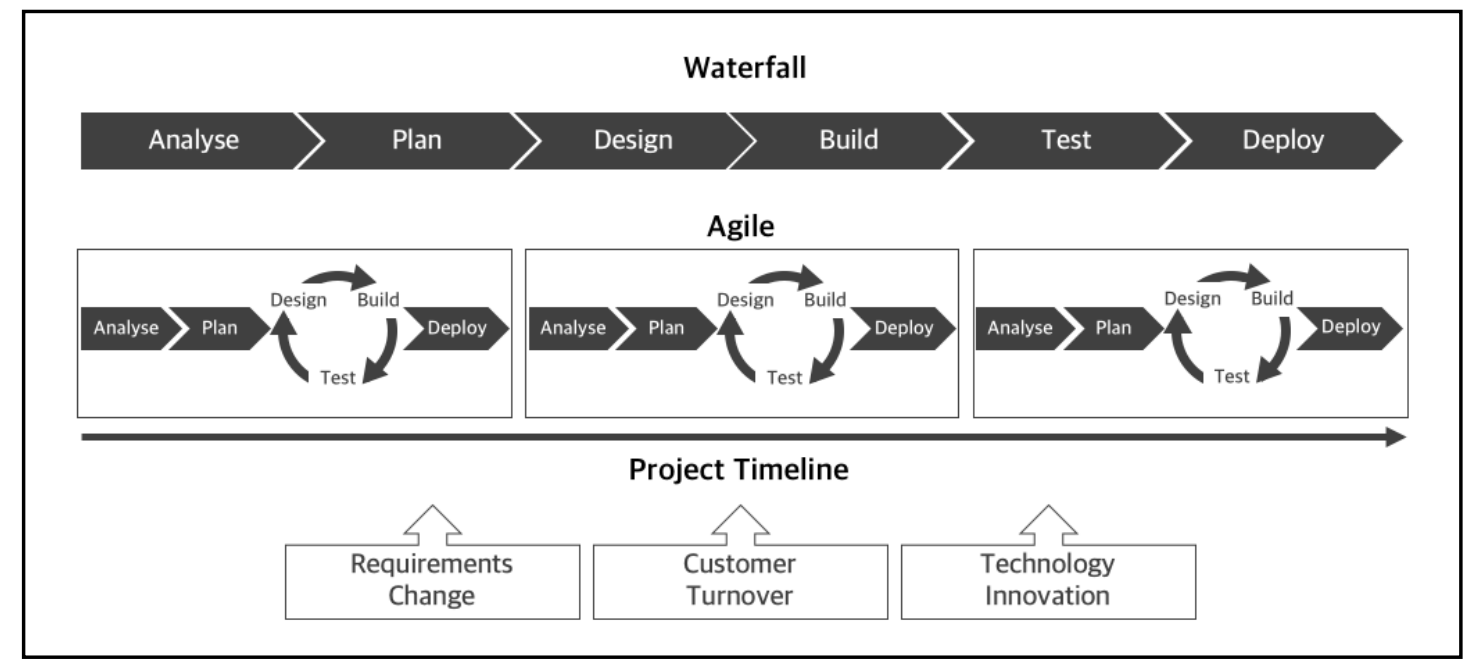

Figure 5 Agile Software Development adapted from Mistral, 2015

Summarising the development of NPD models (Rothwell, 1994; Ortt \& Duin, 2008; Cooper, 2016), is supported by some trends of increasing and particular significance. Firstly, the organisation's capability to develop new products quickly have become an increasingly important aspect in recent years in determining competitiveness, specifically in industries where product cycles are short and technological change rates are high (Rothwell, 1994; Goktan \& Miles, 2011; Cooper, 2014; Chang \& Taylor, 2016). Secondly, simultaneous processing is regarded as another key factor for successful 
NPD management, with cross function teams working independently which improves the speed, efficiency and flexibility of the NPD process (Williamson \& Yin, 2014). Thirdly, unlike NPD approaches in the industrial era, which chiefly relied on information from internal research, recent approaches (e.g. open innovation) are more likely to look outside the company, such as to customers, competitors, and suppliers, in order to find new strategic partners and build comprehensive networks to have more value and competitive advantage (Chesbrough, 2006).

Although a comprehensive set of literature surrounding NPD approaches has been discussed, and indeed successfully applied (Cooper, 1994; Chesbrough, 2003; Hansen \& Birkinshaw, 2007; Sheu \& Lee, 2011; Williamson \& Yin, 2014), it is clear that established NPD processes are still too timeconsuming, with many that either are simply a waste of time or are cost ineffective. (Cooper, 2016; Ortt \& Duin, 2008; Sheu \& Lee, 2011; Cooper, 2014). More importantly, NPD processes reflecting the nature of IoT product and service development are limited in number. Emerging NPD approaches for IoT are now required since the field of innovation management must adapt to a changing economic, societal and technological context in this digitized era. Therefore, the attention of this discussion will focus upon the key factors that are influencing the development process for loT products and services and how they differentiate from existing NPD processes.

\section{What factors differentiate traditional NPD to NPD for loT}

Yoo et al (2010) argues that to understand the nature of digital innovation, one must understand how digital technology differs from earlier technologies, in other words, characteristics of digital technologies; the reprogrammability, the homogenisation of data, and the self-referential nature of digital technology. The reprogrammability refers to a digital device that is, reprogrammable, allowing the device to perform a wide array of functions (Yoo et al., 2010). The homogenisation of data means that any digital content which can be stored, transmitted, processed, and displayed, can be combined easily with other digital data to deliver diverse services which blurs the boundaries of product and industries (ibid, 2010). Finally, the self-referential means that digital innovation requires the use of digital technology which allows fostering further digital innovation through a virtuous cycle of lowered entry barriers, costs, and accelerated diffusion rates (ibid, 2010).

The six dimensions of digital innovation, identified by Yoo et al (2010), are also associated with both innovation outcomes (convergence, and digital materiality) and innovation processes (generativity, heterogeneity, locus of innovation, and pace).

The first dimension of digital innovation is digital convergence. Since digitized technologies share the same infrastructural capabilities, which open novel opportunities for products and services (Tilson et al, 2010), convergence refers to continuous integration of diverse and heterogeneous technologies through homogenization of digital data (Yoo et al, 2010). This therefore changes the nature of products towards becoming digital platforms: e.g., an automobile has become a mobile computing platform (ibid, 2010). More artefacts interacting with other digital devices, provide novel user experience: e.g., GPS (Global Positioning Systems) service in mobile phones, when combined with cars or clothing, deliver an array of service and innovation which connects previously disconnected customer experiences and creates a new kind of virtual physical world (ibid, 2010). Consequently, digital convergence will affect the process of developing loT products and services in which firms need to differentiate user experience offerings, but consider the combination of devices, services and contents and then the interactions with other competitive digital devices and environment in which the loT products operate.

Secondly, digital materiality differentiates NPD processes significantly to their counterparts of physical materiality. Physical materiality refers to artefacts that can be seen and touched, that are generally hard to change, whereas digital materiality refers to what the software incorporated into an artefact can do by manipulating digital representations (Yoo et al, 2012) which allows designers to expand existing physical materiality by "entangling" it with software-based digital capabilities (Yoo et al, 2010; Zammuto, Griffith, Majchrzak, Dougherty, \& Faraj, 2007) when they develop loT 
products and service. loT products can be defined not by their physical materiality but also by fundamental functionality enabled by digital materiality. Trainers or toothbrushes could be an example of physical materiality, however when it contains a microchip in the trainers or a toothbrush that then can be programmed to record a user's amount of physical activity or health status of user's gum, it presents new experiences as digital materiality.

Generativity refers to the way actors, who were not directly involved in the original creation of a technology; begin to create devices, services, and contents which may not be consistent with the original purpose of the artefacts (Zittrain, 2006). An illustrative example of generativity is smartphones with apps, due to its reprogrammable nature, novel functions or capabilities can be added after a device has been produced and launched (Yoo et al, 2012). Higher levels of generativity allow higher numbers of novel ideas, which result in faster innovation cycles with increased iteration, that are more dynamic, agile innovation process than linear approach models (Yoo et al, 2010).

Heterogeneity refers to the integration of diverse forms of data, information, knowledge, and tools and locus of innovation refers to dramatic geographical and social dispersion of innovation sites and processes due to low communication and storage cost (ibid, 2010). New forms of innovation, such as crowd sourcing and open source, enable the locus of innovation moving from inside an organisation to its periphery and edges (ibid, 2010). Both of them affect loT product and service development processes in terms of enabling: independent innovation at different layers of digital service architecture; and innovation activities towards the periphery of the innovation network (ibid, 2010) both physically and geographically. As a number of innovations spurred by Apple's iPhone came from a number of app developers, rather than Apple itself, the de-centering of innovation activities pushes intelligence toward the edge of the organisation's enlarging network (ibid, 2010).

The last dimension of digital innovation is pace. Pace refers to how frequently firms need to innovate, the speed to innovation, and the required speed of diffusion (ibid, 2010). Increased pace affects loT product development processes in which innovation needs to be continuous, incessant, and fast, and allows an industry to increase the role of digital artefacts (ibid, 2010).

Unlike traditional products which have a fixed, discrete set of boundaries and features, distinctive characteristics of loT products are malleable, editable, open, transferable, etc. (Yoo et al., 2010; Zittrain, 2008; Henfridsson et al., 2014), delineated as "ambivalent ontologies" (Kallinikos, Aaltonen, \& Marton, 2013). The scope, features and value of digital offerings can continue to evolve even after the innovative product has been launched or implemented, thus a new approach towards loT product and service development should be identified. Moreover, most loT designs are launched incomplete and in a state of flux in which both the scale and scope of the innovation can be expanded by various participating actors (Hanseth \& Lyytinen 2010). Thus, this conveys an unprecedented level of unpredictability and dynamism in accordance with assumed structural or organisational boundaries of digital innovation, be it a product, platform, or indeed a service.

\section{Emergent approaches towards developing loT based products and services}

Although, the number of study on emergent approaches towards developing loT based product and services, Figure 6. (below) is a new approach, which is developed as a process for designing digital public space by Jacobs \& Cooper (2018). This model is developed by combining existing NPD models, which can focus on underlying principles, and related tools that must be taken into consideration when designing Digital Public Space (Jacobs \& Cooper; 2018) 


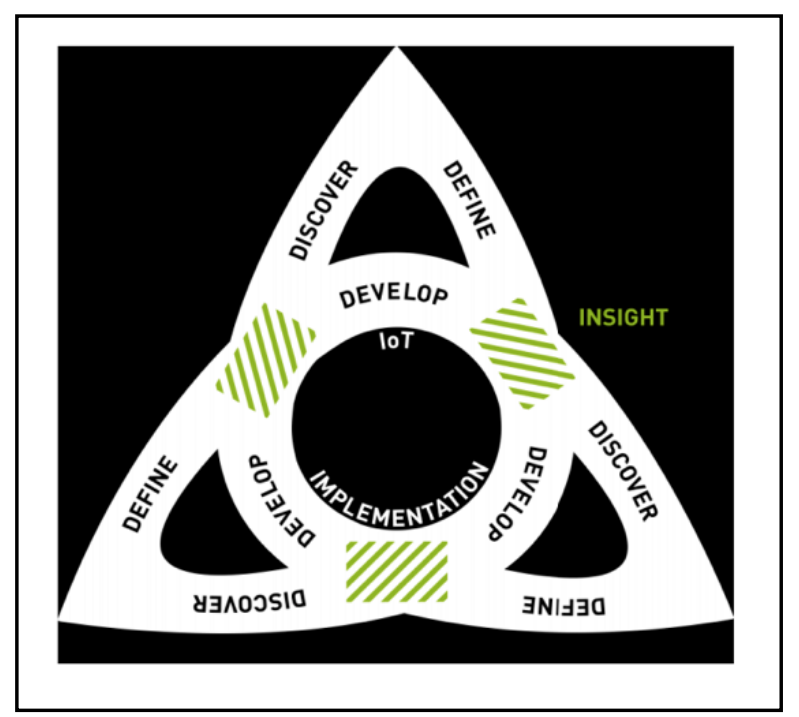

Figure 6 A new process for designing loT products and services. source: Jacobs \& Cooper, 2018

One of the most distinctive attributes different to the existing NPD and NSD processes is that the new approach is not linear, but it is a continuous and emergent process, whereby; the Discovery phase enables co-design and collaboration to uncover the requirements and attributes crucial for the space. The Define phase uses narratives, scenarios and fictions to visualise and test the design idea before the Development phase, through which the products and services are created with users and lead adopters and implemented, with in use insight revealing emergent and new qualities that feed another cycle of discover, define and develop (Jacobs \& Cooper; 2018)

This is because unlike tangible components, which get functionality at the time of production, digital components in loT are able to modify subsidiary functionality, add supplemental functionality, or introduce entirely new functionality over the product lifecycle (Henfridsson et al., 2014). Not only one of the characteristics of digital technology, reprogrammability, but also digital materiality and pace which of the six dimensions of digital innovation, affect the scope, feature and value of loT products and services can continue to evolve even after the innovation has been launched.

Consequently, NPD processes for loT has continuous and never-ending process cycle, which means that loT products and services are able to keep evolving for enhanced customer experiences.

Secondly, the process should contain a short cycle of discover, define and develop phase, which is comparable to the 'agile' approach, one of the existing software development approach with shorter, faster iterations within the process. The approach is feasible in loT product and service development processes due to pace and generativity, and the dimensions of big data that are commonly referred to as the $3 \mathrm{Vs}$ : volume, velocity, and variety (McAfee \& Brynjolfsson, 2012; Meta Group, 2001). As big data aids companies to acquire the massive volume of diverse market information promptly so that they are more easily to meet customer needs (Slater \& Narver, 1995; Zhang, Wu, \& Cui, 2015), it leverages the new approach towards development process for loT. It is identified that companies, which use big data and analytics in their innovation processes, are $36 \%$ more likely to beat their competitors in revenue growth and operating efficiency (Marshall, Lievens, \& Blazevic, 2015).

Another attribute can be explained with one of the traits of innovations associated with pervasive digital technology, which is the emergence of distributed innovations (Yoo et al., 2012). Although it is not clearly shown in the model above (Figure 6), during the process of developing loT products and services, the control over innovation activities are occurred across organisations (Chesbrough, Vanhaverbeke, \& West, 2006; von Hippel 2005) due to the fact that the use of IT enables to reduce communication costs so that democratize the innovation process, involving more of distributed actors which is referred as self-referential nature of digital technology, locus of innovation, and generativity (Yoo et al., 2010). 
Value in the loT will be created through the transformation of customer experiences; companies need strong capabilities in experience design (Burkitt, 2014) which is as offerings, more entwined in a collaborative network of technology, people, and other offerings (Jacobs \& Cooper; 2018). In essence, designing Internet of Things requires the design of - the physical object; its software interface; its hardware interface; how it interacts with other devices over the network; how it is represented on a network to people and to other devices (Jacobs \& Cooper; 2018). This indicates that design for loT can encompass and influence a wide range of design disciplines.

\section{Conclusion}

As novel and challenging as today's loT is, it offers fertile opportunities for long-term sustainable growth for the organisation. Due to its nascent status, there is still a paucity of academic studies on the development process of loT products and services, which is one of the most critical marketing planning and implementation process activities. Although the demands of a new approach towards developing new loT products and services has received widespread attention, there are limited studies that focus upon this emergent topic. Connected devices offer new possibilities for everything from preemptive maintenance to new services and business models. In order to prepare for what is coming, business managers need to consider the new aspects of loT development process in relation to their own business and the ecosystem of partners, as well as emerging technology.

The main purpose of this study is to examine traditional NPD and NSD processes, considering factors that differentiate loT products and traditional products in order to investigate if they are relevant to NPD activities for loT. In exploring this theme, the paper draws attention to the primary research questions at large: What are the characteristics of existing NPD and NSD processes and their relevance to loT product and service development activities? What are the key factors affecting the development of IOT NPD processes, and how they differentiate them from their non-digital counterparts? What are the new attributes required towards loT product and service development activities?

The authors have argued that the characteristics of existing NPD and NSD processes are identified as: established NPD processes are too time-consuming, with many that either are simply redundant or are cost ineffective; the firm's capability to develop new products efficiently have become an increasingly important aspect; simultaneous processing is regarded as another key factor for successful NPD management. Development processes are more likely to involve the customers, competitors, and suppliers, although, NPD and NSD processes are evolving, overcoming their shortcomings, traditional NPD approaches are not reflecting the nature of loT product and service development.

Yoo et al (2010) identified six dimensions of digital innovation, which are associated with innovation outcomes (convergence, and digital materiality) and innovation processes (generativity, heterogeneity, locus of innovation and pace). Three characteristics of digital technology, the reprogrammability, the homogenisation of data, and the self-referential nature of digital technology, are uncovered by Yoo et al (2010). The dimensions of big data, referred to as the $3 \mathrm{Vs}-$ Volume, Velocity, and Variety, which are relevant to the process of developing loT products and services as identified by McAfee and Brynjolfsson (2012), and Meta Group (2001). Henfridsson et al (2014) discover influences of digital technology that affect design flexibility and design scalability. These key factors are identified as the main reasons that differentiate the loT development process away from existing NPD processes. However, not all the factors deeply influence the loT design and development process. Factors, such as reprogrammability, digital materiality, pace, generativity, selfreferential nature of digital technology, dimensions of big data, and locus of innovation are closely related to differentiation of IOT NPD processes from their non-digital counterparts.

Finally, this paper referred to a new process for designing Digital Public Space (Jacobs \& Cooper; 2018) in order to explain the three attributes required towards loT product and service development activities; this new approach should be a continuous and emergent process. The development 
process should contain a short cycle of discovery, definition and development phases; the activities during the process of developing loT products and services should involve more distributed actors and stakeholders input.

Although this paper has explored issues related to the NPD/S process for the loT there, is some limitation that need to be addressed by further research. Firstly, further key factors need to be considered such as the size of the loT ecosystem in which new products and services are developing, alongside the dimensions of digital innovation, artifacts and technology and the loT firm's business strategy in comparison to a traditional company strategy. Although it is fair to say that many businesses with be both engaged in traditional NPD and IOT NPD. Secondly, relying solely on a limited literature review in order to identify new approach towards developing new products and services for loT where only a limited number of studies have been discovered. Consequently, this paper has identified related and practical questions for further research: What are the key factors that differentiate the traditional NPD and emerging NPD for loT in terms of its business strategy and process changes?; Is there a generic loT product and service development process in the loT industry? And finally, what is the NPD process for loT firms, which create meaningful value and increased turnover for all its primary stakeholders?

\section{References}

Anderson, R. E. (1993). 'HRD's Role in Concurrent Engineering,' Training \& Development 47 (6):49

Awwad, A., \& Akroush, N. M. (2016). New product development performance success measures: an exploratory research, EuroMed Journal of Business, Vol. 11 Issue: 1, pp.2-29

Baker, M., \& Hart, S. (1999). Product Strategy and Management. Harlow: Financial Times Prentice Hall, Hernel Hempstead.

Beck, K., Beedle, M., van Bennekum, A., Cockburn, A., Cunningham, W., \& Fowler, M. et al. (2001, 20 Oct 2017). Manifesto for Agile Software Development. Retrieved from http://agilemanifesto.org/

Begel, A., \& Nagappan, N. (2007). Usage and perceptions of agile software development in an industrial context: An exploratory study. (255-264). Washington, US: ESEM '07: First International Symposium on Empirical Software Engineering and Measurement, DC: IEEE

Booz, Allen \& Hamilton. (1982). New Product Management for the 1980s, New York: Booz, Allen \& Hamoilton.

Bruce, M., \& Cooper, R. (2000). Creative Product Design: A practical guide to requirements capture management, London: John Wiley \& Sons, LTD, 2000 p11-15

Burkitt, F. (2014). A Strategist's Guide to the Internet of Things: The digital interconnection of billions of devices is today's most dynamic business opportunity, PWC, Issue 77, Winter, 2014

Caputo, M., Lamberti, E., Cammarano, A., and Michelino, F. (2016). Exploring the impact of open innovation on firm performances, Management Decision, Vol 54, No. 7.

Chang, W., \& Taylor, S. A. (2016). The effectiveness of customer participation in new product development: a meta-analysis. Journal of Marketing, 80, 47-64.

Chesbrough, W. H. (2003). Open Innovation: The New Imperative for Creating and Profiting from Technology. Cambridge: Harvard Business Press.

Chesbrough, W. H. (2004). Open Innovation: Renewing Growth from Industrial R\&D, $10^{\text {th }}$ Annaul Innovation Convergence, Minneapolis, Sep $27^{\text {th }}, 2004$

Chesbrough, W. H. (2006). Managing Open Innovation, Research-Technology Management, 2004, Vol.47, Issue 1, pp.23-26

Chesbrough, W. H., Vanhaverbeke, W., \& West, J. eds. (2006). Open Innovation: Researching a New Paradigm. New York: Oxford University Press.

Cisco IBSG (2011) The Internet of Things: How the Next Evolution of the Internet Is Changing Everything, Cisco IBSG, Apr 2011.

Cooper, G. R. (1990). Stage-Gate Systems: A New Tool for Managing New Products, Business Horizons, MayJune 1990, pp.44-54

Cooper, G. R. (1994). Third Generation New Product Processes, Journal of Product Innovation Management, vol. 11, pp. 3-14

Cooper, G. R. (2005). Product Leadership, USA: Basic Books.

Cooper, G. R. (2014). what's next? After stage-gate. Research Technology Management, 57(1), 20-31. 
Cooper, G. R. (2016). Agile-Stage-Gate Hybrids: The Next Stage for Product Development, Research-Technology Management, 59:1, 21-29

Cooper, G. R. (2017). We've Come a Long Way Baby, Journal of Product Innovation Management, 2017; 34(3):387-391

Crawford, C. M. (1997). New Products Management (5 ${ }^{\text {th }}$ ed.). McGraw-Hill, Inc.

Durisin, B., Calabretta, G., \& Parmeggiani, V. (2010). The Intellectual Structure of Product Innovation Research: A Bibliometric Study of the Journal of Product Innovation Management, 1984-2004, Journal of Product Innovation Management, 2010; 27:437-451

European Commissions Information Society. (2008). Internet of things in 2020: a roadmap for the future. In reports of DG INFSO \& EPoSS-05. Sep 2008

Eveleens, C. (2010). Innovation Management; A literature review of innovation process models and their implications, Science, 800, 900.

Gartner. (2014, 10 Oct 2017). Gartner says the Internet of Things will transform the data center. Retrieved from https://iot.do/gartner-says-internet-things-will-transform-data-center-2014-03

Giudice, D. M. (2015). Discovering the Internet of Things within the business process management: A literature review on technological revitalization, Business Process Management Journal, Vol.22 No. 2, 2016 pp.263270

Goffin, K., \& Koners, U. (2011). Tacit Knowledge, Lessons Learnt and New Product Development, Journal of Product Innovation Management, 2011; 28:300-318

Goktan, A. B. \& Miles, G. (2011). Innovation speed and radicalness: are they inversely related? Management Decision, 49, 533-547.

Hauser, R. J., \& Dahan, E. (2007). New Product Development. In: Weitz, B. \& Wensley, R. (eds.) Handbook of Marketing. London, Sage

Hansen, M. T., \& Birkinshaw, J. (2007). The innovation value chain. Harvard Business Review, 85, $121-130$.

Hanseth, O., \& Lyytinen, K. (2010). Design theory for adaptive complexity in information infrastructures. Journal of Information Technology.

Harmancioglu, N., McNally, C. R., Calantone, J. R., \& Durmusoglu, S. S. (2007). Your new product development (NPD) is only as good as your process: an exploratory analysis of new NPD process design and implementation, R\&D Management, 2007, 37, 5, pp.399-424

Henfridsson, O., Mathiassen, L., \& Svahn, F. (2014). Managing technological change in the digital age: The role of architectural frames. Journal of Information Technology, 29(1), 27-43.

ITU. (2005, 19 Sep 2017). The internet of things-executive summary. International Telecommunication Union (ITO) Internet Report. Retrieved from http://www.itu.int/osg/spu/publications/internetofthings

Jacobs, N., \& Cooper, R. (2018). Living in Digital Worlds: Designing the Digital Public Space. Routledge. in press

Johnson, S. P., Menor, L. J., Chase, R. B., \& Roth, A.V. (2000). A critical evaluation of the new services development process: integrating service innovation and service design, in Fitzsimmons, J.A. and Fitzsimmons, MJ. (Eds), New Service Development Creating Memorable Experiences, Thousand Oaks, CA: Sage Publications.

Johnson, S. J., Friend, B. S., and Lee. S. H. (2017). Big Data Facilitation, Utilization, and Monetization: Exploring the 3Vs in a New Product Development Process, Journal of Product Innovation Management, 2017; 34(5):640-458

Kallinikos, J., Aaltonen, A., \& Marton, A. (2013). The Ambivalent Ontology of Digital Artefacts, MIS Quarterly, June 2013, Vol. 37 No. 2, pp. 357-370

Kessler, H. E., \& Bierly III, P. E. (2002). Is Faster Really Better? An Empirical Test of the Implication of Innovation Speed, IEEE Transactions on Engineering Management, Vol. 49, Issue. 1, Feb 2002

Krishnan, V., \& Ulrich, T. K. (2001). Product Development Decisions: A Review of the Literature, Management Science, Vol. 47, No.1, Jan 2001, pp.1-21

Lee, I., \& Lee, K. (2015). The Internet of Things (IoT): Applications, investments, and challenges for enterprises. Business Horizons, Vol. 25, Issue. 4, Jul-Aug 2015, pp431-440

Machado, A. M. (2013). New Product Development: From Efficiency to Value Creation, 2013 Proceedings of PICMET' 13: Technology Management for Emerging Technologies, pp. 1542-1549.

Marshall, A., Mueck, S., \& Shockley, R. (2015). How leading organizations use big data and analytics to innovate. Strategy \& Leadership, 43 (5): 32-39.

McAfee, A., and Brynjolfsson, E. (2012). Big data: The management revolution. Harvard Business Review 90 (10): 60-68. 
Meta Group. (2001). 3D data management: Controlling data volume, velocity and variety. Gartner. Retrieved from http://blogs.gartner.com/doug-laney/files/2012/01/ad949-3D-Data-Management-Con-trolling-DataVolume-Velocity-and-Variety.pdf.

Meyer, M. H., \& Utterback, J. M. (1995). Product development cycle time and commercial success. IEEE Transactions on Engineering Management, 42: 297-304

Mistral (2015, $8^{\text {th }}$ Sep 2017) Agile in BI Projects-Introduction, Retrieved from http://www.mistralbs.com/blog/i/173/130/agile-in-bi-projects-introduction

Oorschot, K. V., Sengupta, K., Akkermans, H., \& Van Wassenhove, L. (2010). Get Fat Fast: Surviving Stage-Gate in NPD. Journal of Product Innovation Management, 27(6), 828-839.

Ortt, J. R., \& van der Duin, P. A. (2008). The evolution of innovation management towards contextual innovation. European Journal of Innovation Management, 11, 522-538.

Ovesen, N., \& Sommer, A. F. (2015). Scrum in the traditional development organisation: Adopting to the legacy. In Modelling and Management of Engineering Processes, Proceedings of the $3^{\text {rd }}$ International Conference 2013, (pp. 87-99). Berlin: Springer-Verlag.

Pennell, P. J., Winner, I. R., Bertrand, E. H., \& Slusarczuk, M. G. M. (1989) Concurrent engineering: An overview for Autotestcon, IEEE Automatic Testing Conference Proceedings, (pp.88-99).

Pisano, P., Pironti, M. and Rieple. A. (2015). Identify innovative business models: Can innovative business models enable players to react to ongoing or unpredictable trends? Entrepreneurship Research Journal, 5 (3): 181-99.

Porter, E, M. \& Heppelmann, E, J. (2014). How Smart, Connected Products Are Transforming Competition, Harvard Business Review, Nov. 2014, pp.64-88

Rothwell, R. (1994). Towards the fifth-generation innovation process. International Marketing Review, 11, 731.

Schilling, M. A., \& Hill, C. W. L. (1998). Managing the New Product Development Process: Strategic Imperatives, The Academy of Management Executives 12 (3):67

Sheu, D.D., \& Lee, H. (2011). A proposed process for systematic innovation. International Journal of Production Research, 49, 847-868.

Slater, F. S., \& Narver, C. J. (1995). Market orientation and the learning organization. Journal of Marketing, 59 (3): 63-74.

Smith, P.G. (2007). Flexible product development: building agility for changing markets, John Wiley and Sons, New York.

Stevens, E., \& Dimitriadis, S. (2005). Managing the new service development process: towards a systemic model, European Journal of Marketing, Vol. 39 Issue: 1/2, pp. 175-198

Takeuchi, H., \& Nonaka, I. (1986). The new Conduct Development Game, Harvard Business Review Jan/Feb: 137-146.

Tidd, J., \& Bessant, J. (2005). Managing Innovation: Integrating Technological, Market and Organizational Change (3rd ed.). Chichester: John Wiley \& Sons.

Tilson, D., Lyytinen, K., \& Sorenson, C. (2010). Desperately seeking the infrastructure in research: Conceptualization of "digital convergence" 43rd HICSS.

Trott, P. (2012). Innovation Management and New Product Development (5 ${ }^{\text {th }}$ ed.). London: Person Education von Hippel, E. (2005). Democratizing Innovation. MIT Press, Cambridge, MA.

Williamson, P. J., \& Yin, E. (2014). Accelerated innovation: the new challenge from China. MITS loan Management Review, 55, 27-34.

Yoo, Y., Boland, R. J., Jr., Lyytinen, K., \& Majchrzak, A. (2012). Organizing for innovation in the digitalized world. Organization Science, 23(5), 1398-1408.

Yoo, Y., Lyytinen, K.J., Boland, R. J. Jr., \& Berente, N. (2010, 10 Sep 2017). The next wave of digital innovation: Opportunities and challenges: A report on the research workshop 'digital challenges in innovation research.' Retrieved from https://papers.ssrn.com/sol3/papers.cfm?abstract_id=1622170

Zammuto, F. R., Griffith, L. T., Majchrzak, A., Dougherty. J. D., \& Faraj, S. (2007). Information technology and the changing fabric of organization. Organ. Sci. 18(5):749-762.

Zhang, H., Wu, F., and Cui, S. H. (2015). Balancing market exploration and market exploitation in product innovation: A contingency perspective. International Journal of Research in Marketing 32 (3): 297-308.

Zittrain, J. (2006). The generative internet. Harvard Law Review 119 1974-2040. 
About the Authors:

Lee, Boyeun is a PETRAS PhD student at Lancaster University, after having a wide range of public and commercial experience across sectors as a service designer in Korea. Her research interests cover: design thinking; service design; design management; and design policy.

Prof. Cooper, Rachel OBE is Distinguished Professor of Design Management and Policy at Lancaster University. Her research interests cover: design thinking; design management; design policy; and across all sectors of industry, a specific interests in design for wellbeing and socially responsible design.

Dr Hands, David is Director of Postgraduate Studies at Lancaster Institute of Contemporary Arts, Lancaster University. David has also written and published extensively on design management and design as a strategic resource for both profit and non-profit organisations alike. 